\title{
Kutluay Erk
}

BOOK REVIEW: APATÓCZKY, Á.B., ATWOOD, Ch.P. (EDS.), KEMPF, B. (G.-ED.). 2018. PHILOLOGY OF THE GRASSLANDS: ESSAYS IN MONGOLIC, TURKIC, AND TUNGUSIC STUDIES. LEIDEN; BOSTON: BRILL (THE LANGUAGES OF ASIA. VOL. 17)*

Professor György Kara, a distinguished member of academia, celebrated his 80th birthday recently. His students and colleagues commemorated this occasion with papers on Altaic Studies. The work, which consists of 24 articles, was edited by Ákos Bertalan Apatóczky and Christopher P. Atwood, and guest-edited by Béla Kempf. The main topics discussed in the work are Manuscripts-Texts Analyse, Sino-Mongol Glossaries, Middle Turkic, Middle Mongolian, Oirat, Tungus, Modern Mongolian, Khalka, Kipchak, Morphology.

Key words: review, altaistic, mongolian, philology, analyse.

About the author: Erk Kutluay, PhD (Philology), Ege University, Institute of Turkish World Studies, Department of Turkish Language and Dialects.

Contact information: 35040, Turkey, Bornova/İzmir, Ege University, Institute of Turkish World Studies; e-mail: kutluay.erk@windowslive.com.

\section{Кутлуай Ерк}

\section{РЕЦЕНЗИЯ НА КНИГУ: АПАТОЦКИ А.Б., ЭТВУД К.П. (РЕД.), КЕМПФ Б. (ПРИГЛ. РЕД.). 2018. ФИЛОЛОГИЯ ПАСТБИЩ: ОЧЕРКИ НА МОНГОЛЬСКОМ, ТЮРКСКОМ И ТУНГУСОВЕДЕНИЕ. ЛЕЙДЕН; БОСТОН: БРИЛЛЬ (ЯЗЫКИ АЗИИ. Т. 17)}

Профессор Дьёрдь Кара, выдающийся академик, недавно отпраздновал свое 80-летие. Его ученики и коллеги отметили это событие докладами по алтайологии. Работа, состоящая из 24 статей, была отредактирована Акошом Берталаном Апатоцки и Кристофером П. Этвудом и приглашенным редактором Белой Кемпф. Основными темами, обсуждаемыми в работе, являются анализ рукописей-текстов, синомонгольские глоссарии, среднетюркский, среднемонгольский, ойратский, тунгусский, современный монгольский, халка, кипчакский, морфология.

Ключевые слова: обозрение, алтаистика, монгольский язык, филология, анализ.

Сведения об авторе: Ерк Кутлуай, PhD (Philology), Эгейский университет, Институт изучения тюркского мира, кафедра турецкого языка и диалектов.

Контактная информация: 35040, Турция, Боснова/Измир, Эгейский университет, Институт изучения тюркского мира; e-mail: kutluay.erk@windowslive.com.

\footnotetext{
* Статья поступила в номер 14 июля 2021 г.
} Принята к печати 01 августа 2021 г. 
A large number of works have been published in honor of the birthday of György Kara, a Hungarian Orientalist, philologist, mongolist, and a distinguished member of the Hungarian Academy of Sciences. First of these "Türk Dilleri Araştırmaları, Cilt 10, Festschrift für György Kara, anläßlich seines 65. Geburstages am 23. Juni 2000, İstanbul-Berlin" edited by Talat Tekin and Mehmet Ölmez. The second is "The Black Master: Essays on Central Eurasia in Honor of Gyorgy Kara on His 70th Birthday, 2005" edited by Agnes Birtalan, Stephane Grivelet, Ruth I Meserve, Giovanni Stary. The third is the work edited by Ákos Bertalan Apatóczky, Christopher P. Atwood, and (guest-edited) by Béla Kempf, which is the subject of our review. The mentioned work consists of 24 articles. To better analyze these articles, we have divided them into two groups: Historical Studies, Modern Studies. These two main headings include the following subheadings: Manuscripts-Texts Analyse, Sino-Mongol Glossaries, Middle Turkic, Middle Mongolian, Oirat, Tungus, Modern Mongolian, Khalka, Kipchak, and Morphology.

\section{Historical Studies}

\subsection{Manuscripts-Texts Analyse}

A total of six articles about various fragments, texts, and manuscripts are seen in the work. The first of these is the article entitled "Some Remarks on Page Fragments of a Mongol Book of Taoist Content from Qaraqota" by Otgon Borjigin. The fragments analyzed in this article are the remains of two adjacent leaves in a rectangular xylographic book inscribed with Uyghur-Mongol script. The main value of texts containing interlinear Chinese glosses for the Taoist terms and Chinese personal and place names, is that it is the remainder of the early Mongolian translation of the Chinese Taoist work. Subheadings in the article are the following: Synopsis of the Text, Punctuation, and Orthography, Transcription, Translation of the Text and Notes, Index. Another article is titled "A Mongolian Text of Confession" by Olivér Kápolnás and Alice Sárközi. The analyzed text is a booklet named Tabun čoyča-yin sudur "Sūtra of the five aggregates". The text consists of the following parts: Veneration to the three jewels and to the thirty-five Buddhas of Confession, List of sins and the punishments, List of virtues and rewards, Request for remission of sins. In the article titled "Kollektaneen zum Uigurischen Wörterbuch: Zwei Weisheiten und Drei Naturen im uigurischen Buddhismus" by Klaus Röhrborn, examines the relationship between the two wisdoms of Mādhyamika Buddhism and the three natures of Vijñānavāda (the two excellent wisdoms "iki törlüg yeg bilgä biliglär", the three natures or beings "üč törlüg tözlär”). Another article written in this category is Svantesson's article entitled Spelling Variation in Cornelius Rahmn's "Kalmuck Manuscripts as Evidence for Sound Changes". In this work author analysed the spelling variations found in Cornelius Rahmn's Kalmuck manuscripts, point out some general patterns that are significant for the phonological history of the language, and leaving a detailed interpretation to specialists of the Kalmuck language. Zum Werktitel mongolischer Texte seit dem 17. Jahrhundert by Michael Weiers "On the Working Titles of Post-17th century Mongolian Texts". In his article Weiers studies and characterizes the particular textual choices of Mongol authors of the period when choosing words to lead off their works, and introduce them to the world. In the process, often making detailed comparisons within his well-founded selection of examples, thereby defining the characteristics of the texts in question, comparing them, and even creating a typology, where appropriate, Weiers also re-interprets them. The article is carefully documented with full information about each of the texts in question, which are then compared in detail in each case to other such texts discussed. Throughout his study, Weiers is very meticulous in his discussions and most of the article is taken up by his comparative individualized discussions. Wu Yingzhe in his 
article titled "The Last-Words of Xiao Chala Xianggong in Khitan Script" interprets the "last words" of the tomb owner, which newly found Epitaph of Xiao Chala Xianggong (bilingual inscription in Khitan and Chinese). In this article, referring to the Chinese version and those Khitan words already deciphered, those words which have not been explored yet have been deciphered. Through this bilingual record, the root meanings and their derivations for some Khitan words examined.

\subsection{Sino-Mongol Glossaries}

The first article on Sino-Mongol Glossaries is the article entitled The Yibu (譯部) Chapter of the “Lulongsai lüe (盧龍塞略)" by Ákos Bertalan Apatóczky. The text analyzed in this article is a chapter incorporated in the Lulongsai lüe, a 17th century comprehensive Chinese military work called the Lulongsai lüe. The article by Pavel Rykin analyzes the Proto-Mongolian Vocabulary in a little-known late 16th - early 17th century Sino-Mongolian glossary in terms of the reflexes of the $* \mathrm{VgV}$ and $* \mathrm{VxV}$ groups. The two groups are carefully defined by Rykin, with many examples of group derivatives. The stress in the discussion is on improving the reconstruction and understanding of Proto-Mongolian forms and their evolutions. Careful comparisons are made between various Mongolian languages in evaluating the groups and their functions.

\subsection{Middle Turkic}

Middle Turkic Dialects as Seen in Chinese Transcriptions from the Mongol Yuan Era by Christopher P. Atwood. In this article, the records of the Mongol Yuan dynasty (1271-1368), which preserve some transcriptions of Mongolian and Turkic names, are analyzed. The analysis is clasified under three main headings by the author: Anthroponyms of the Öng'üt (central Inner Mongolia), Anthroponyms of the Naiman (western Mongolia), Selected Western Turkic anthroponyms. These tables arranged the data from Chinese transcriptions in parallel with alphabetic scripts (Persian or Mongolian). All words have been compared with subtopics like Chinese transcription, Chinese transcription values, Attested alphabetic transliteration, Etymology, and Demonstrated sound changes (Luvsandèndèv 1957: 32).

\subsection{Middle Mongolian}

The article by Brian Baumann focuses on the allegory and metaphor found in a pre-Classical Mongolian set of verses included in a Sa-sKya-pa treatise on all aspects of salvation. Including. To this end, among another discussion, there is allegory and metaphor apparently directed against women as dirty, smelly and corrupted, and corrupting, as preventing rebirth and salvation. The article discusses the character of this apparent misogyny and its roots in the Buddhist worldview and in monastic asceticism. The paper also looks at the issue of women in other beliefs and belief systems and common elements and differences (Haenisch 1939: 55). "Some Medical and Related Terms in Middle Mongyol" by Volker Rybatzki. In his article, Volker Rybatzki, who by the time of writing was preparing an Etymological dictionary of Middle Mongolian, listed and analyzed Middle Mongolian medical and medically-related terminology, much of which represents old loans in Middle Mongolian. Each example is carefully documented in detail with full source indications and other required information provided (Kara 2009: 27). The article by Elisabetta Ragagnin focuses on the Badəkšaan, "a supernatural creature inhabiting northern Khövsgöl aimag's high taigas", according to the Turkic-speaking Dukhan. It is small, blonde, and addicted to reindeer milk. 
Ragagnin goes on to discuss the Dukhan and their mythical creature in detail. Ragagnin also discusses related topic such as the etymology of the word Badəkšaan and its likely linguistic origins. Also discussed is a possible connection between the mythical Central Asian toponym of Badaǩšān and Badəkšaan the creature.

\section{Modern Studies}

\subsection{Oirat}

Some Aspects of the Language Usage of Darkhat and Oirat Female Shamans Ágnes Birtalan. The article by Ágnes Birtalan focuses on aspects of the language usage of Darkhat and Oirat female shaman, including generalized shamanic usage and a possible specifically female usage. The linguistic and cultural analysis that follows is based on the authors' interviews with shaman and upon her fieldwork. Many terms are discussed in detail and usage among one group of target shaman is compared with usage in others, including usage across languages and cultures. On-going changes in the shaman communities, including political change, are considered by way of background. Proper Names in the Oirat Translation of "The Sutra of Golden Light" Natalia Yakhontova. In her paper, Natalia Yakhontova discusses proper name usage in the Oirat translation of "The Sutra of Golden Light", or Suvanaprabosottama sutra, a major Buddhist text which exists in various versions, including alternative texts due to the vicissitudes of transmission, and in a variety of languages, although the original version was in Sanskrit. She begins by discussing the sutra itself and the various Oirat versions used in the study. Turning to the 150 proper names, applied to various figures in the sutra, major and minor, Yakhontova discusses and compares the names in question by linguistic category, dividing them into original forms and Tibetan-style translations of original forms. The main part of the article consists of a name by name glossary and discussion of all the names by category (Krueger 1978: 65).

\subsection{Tungus}

"Past Tenses, Diminutives and Expressive Palatalization: Typology and the Limits of Internal Reconstruction in Tungusic" José Andrés Alonso de la Fuente. The article by José Andrés Alonso de la Fuente focuses on various linguistic features of the Tungusic languages (particularly the initial segment in the diminutive suffix), and the impact of these features on such things as philological reconstruction. The features described, the author emphasizes, are not exceptional and must be responded to in reconstruction. The author provides and discusses many specific examples to illustrate his points from a variety of Tungusic languages. Early Serbi-Mongolic-Tungusic Lexical Contact: Jurchen Numerals from the 室韋 Shirwi (Shih-wei) in North China by Andrew Shimunek. In his article, Andrew Shimunek examines the origins of the Manchu-Jurchen numerals 11-19, recognized as of known Mongolic character. and constructs a hypothesis that the numerals represent early lexical contact between Serbi or Xianbei 鮮卑, at the time a wide-spread group in Mongolia and connected areas of Central Asia, and the proto-Mongolic language of the Shiwei (Shirwi) 室韋 then located in North China. After offering his hypothesis, Siemunek follows up by discussing the numerals in question themselves, of which there are two types, one of them an aberrant series with distinctly Mongolic characteristics, type 1, and the other showing the form 10 plus number. He goes on to discuss the sources revealing the type one numerals and the forms that the numerals assume in these sources. In conclusion, he details the full historical and linguistic context for the borrowing. Four Tungusic Etymologies Alexander Vovin. In his articled Alexander Vovin examines the 
etymologies of four Tungusic words, namely Manchu Nikan, 'Chinese,' Oroch and Uita ilau, 'ritual whittled piece of wood". Oroch Magiri, Broad Knife for Cutting Bread, Nanai sago, also Kururaii saqo.'Water' (stale of a rusted color). Each word is discussed in a full comparative context with an in-depth citation of the relevant sources (Louis 1945: 61).

\subsection{Modern Mongolian}

"On the Phenomeno-Logic behind some Mongolian Verbs" Ines Stolpe and Alimaa Senderjav. Authors Ines Stolpe and Alimaa Jenderjav discuss the phonomeno-logic behind some Mongolian verbs, namely барих, 'to grasp', and тавих, the second with an absolutely huge range of meanings, illustrating the "Mongolian way of thinking." In their article the authors review the theoretical literature and its implications and then go on to a detailed analysis of lists of idiomatic noun-verb forms of the two chosen verbs, including deverbal forms, to illustrate their own points. Also discussed in this section of the paper are other Mongolian verbs and their derivative forms by way of comparison. Brought in for comparative purposes are examples from languages other than Mongolian. In his "Contraction, anticipation et persévération en mongol xalx: quelques réflexions [Contraction, Anticipation, and Perseveration in Khalkha Mongolian, some thoughts] Jacques Legrand discusses the given linguistic features in detail, with many carefully selected examples, particularly of suffixes, and a careful analysis of examples provided comparatively. How the features described are cooperative together in characteristic ways is shown as well.

\subsection{Khalka}

Pronouns and Other Terms of Address in Khalkha Mongolian Benjamin Brosig. In his Paper, Benjamin Brosig introduces the various Khalkha terms of address and stresses their linguistic and cultural importance in language use, along with the need for proper use, the varying contexts of usage being noted and explained, a theme taken up more than once. After his introduction, Brosig goes on to catalog the various kinds of terms of address and then discusses the inventory of the various terms of address in Khalkha Mongolian by categories, including such things as personal names morphed into terms of address, and compound terms in which an element like min', 'my', is added to increase familiarity and immediacy. The paper not only provides many examples of common usage today but even examples of more specialized and complicated usages, carefully explaining the usages including where a choice of forms exists.

\subsection{Kipchak}

From Tatar to Magyar: Notes on Central Eurasian Ethnonyms in -r Juha Janhunen. In his paper, Juha Janhunen discusses and catalogs the Central Asian ethnonyms, including tribal and clan names, occurring in -r, typical, the author says, of the entire region, extending from Tatar to Magyar. The author attempts to explain why the ethnonym with a final $-r$ is so common in the area stressing coincidence and parallel development as the primary driver of the uniformity. To this end there is a comparative analysis of various ethnonyms of various forms ending in -r, showing how the $-r$ is more often than not functionally different from one - $r$ ethnonym to the other. The examples are organized and discussed by linguistic grouping in full detail. Sino-Mongolica in the Q1rgiz Epic Poem Kökötöy's Memorial Feast by Saġımbay Orozbaq uulu Daniel Prior. Daniel Prior is preparing an English translation of the Qirg̀ız Epic Poem Kökötöy's Memorial Feast by Saġmbay Orozbaq uulu, and draws upon his experience so far to produce notes and annotations on the epic, including a 
great deal of information on noted Qirgiz national figure and author Sagimbay Orozbaq uulu, a Manas-bard. In his discussion, Prior stresses the Sino-Mongolica side of the epic because of the many common elements existing in Eurasia at the time, and author Sagimbay Orozbaq uulu's own travels to Xinjiang around 1916, where he even learned a little Chinese as well as picking up some story elements to drop into his poem, and contacts also with the Mongolian world of the time including many words he borrows or adapts in his work. Saġımbay Orozbaq uulu's heroes also function in a world that Is not only culturally and linguistically, but geographically sophisticated, more so than the comparatively limited geographical world of the Manas (Pyurbeev 2001: 300, 413, 415).

\subsection{Morphology}

The Role of Ewenki VgV in Mongolic Reconstructions Bayarma Khabtagaeva. In her paper, Bayarma Khabtagaeva looks at the Ewenki VgV class of verbs and it use in achieving Mongolian reconstructions. The paper, first of all, establishes the importance of early Mongolic-Ewenki contacts, and stresses, because of the age of the contacts, their potential importance as very old borrowings, for reconstructing early Mongolian forms. The paper then offers a linguistic background for the study, establishing Mongolic-Ewenki connections and their character. Also discussed is the Mongolic intervocalic VGV form. Numerous connected words are also discussed as examples including relevant Ewenki forms, also including early Ewenki borrowings. The Dongxiang (Santa) Ending -ğun and Its Allies Hans Nugteren. Hans Nugteren's paper looks at the Dongxiang (Santa) Ending -ğun and its Allies. The ending -ğun is a specialized ending denoting a generalized location or direction. Nugteren begins by discussing the functions and origin of the suffix, following up with many fully explained examples of usage. In terms of origin, the published etymologies are next fully discussed and explained. This includes a discussion of related forms. This part of the article ends with an alternative etymology, other than the standard published ones. The last part of the article provides tables of usage showing the ending "and its allies" as part of Functional phrases (Chinggeltei 1963: 25; Poppe 1937: 42; Schmidt 1831: 32).

We congratulate the authors and editors who have produced an important work for Altaistic studies by creating this work, which includes outstanding articles. As Ákos Bertalan Apatóczky said Tümen nasulatughai!

\section{References}

Pyurbeev, G. Ts. (ed.). 2001a. Bol'shoy akademicheskiy mongol'sko-russkiy slovar' (Comprehensive academic Mongolian-Russian dictionary). Vol. 1. A-G. Moscow: Academia.

Chinggeltei. 1963. A Grammar of the Mongol Language. New York: Frederick Ungar Publising Co.

Haenisch, E. 1939. Wörterbuch zu Manghol un Niuca Tobca'an. Leipzig: Harrosowitz.

Schmidt, I. J. 1831. Grammatik der Mongolischen Sprache. St.-Petersburg: Kaiserlichen akademie der wissenschaften.

Poppe, N.N. 1937. Grammatika pis'menno-mongol'skogo yazyka (Grammar writing-Mongolian language). Moscow; Leningrad: AN SSSR.

Kara, G., Kiripolská, M. 2009. Dictionary of Sonom Gara's Erdeni-yin sang: a Middle Mongol version of the Tibetan Sa-skya legs bshad: Mongol-English-Tibetan. Leiden; Boston: Brill (Brill's Inner Asian Library 23).

Krueger, Jh. R. 1978. Materials for an Oirat-Mongolian to English Citation Dictionary. Bloomington: Mongolia Society.

Louis, H. 1945. Grammaire de la Langue Mongole Écrite. Paris: Adrien-Maisonneuve.

Luvsandèndèv, A. 1957. Mongol'sko-russkiy slovar' (Mongolian-Russian dictionary). Moscow: Izdatel'stvo Inostrannykh i natsional'nykh slovarey. 